\title{
Nilai-nilai budaya soméah pada perilaku komunikasi masyarakat Suku Sunda
}

\author{
Dasrun Hidayat ${ }^{1}$ dan Hanny Hafiar ${ }^{2}$ \\ ${ }^{1}$ Universitas Bina Sarana Informatika, Bandung, Indonesia \\ ${ }^{2}$ Universitas Padjadjaran, Bandung, Indonesia
}

\begin{abstract}
ABSTRAK
Penelitian ini didasari oleh keingintahuan tentang budaya soméah sebagai ciri khas yang melekat pada masyarakat Suku Sunda. Penelitian bertujuan untuk mengetahui secara spesifik tentang nilai-nilai budaya soméah termasuk implikasi dan aplikasinya pada perilaku komunikasi masyarakat Suku Sunda. Untuk menjawab tujuan tersebut, peneliti menggunakan teknik pengumpulan data melalui wawancara dan observasi. Menggunakan pendekatan kualitatif dengan paradigma konstruktivis dan studi etnografi public relations, studi yang berfokus pada kajian budaya dengan pendekatan teori public relations. Penelitian menemukan bahwa budaya soméah mengandung nilai-nilai kerendahan hati, kesopanan dan keramahan. Nilai-nilai tersebut merepresentasikan brand personality masyarakat Suku Sunda. Hal ini selaras dengan filosofi hidup mereka yaitu Soméah Hade ka Sémah yang artinya ramah, bersikap baik, menjaga, menjamu dan membahagiakan setiap orang. Implikasi dan aplikasi nilai-nilai filosofi hidup tersebut terdapat pada setiap perilaku komunikasi yang terjadi secara berulang di lingkungan internal dan eksternal. Perilaku komunikasi dengan menggunakan bahasa punten dan mangga. Bahasa punten mengandung makna kerendahan hati. Sedangkan penggunaan istilah mangga sebagai wujud penawaran, ajakan, mempersilahkan dan permohonan. Hasil penelitian ini juga menemukan bahwa terdapat dua aspek yang membuktikan bahwa masyarakat Suku Sunda merupakan pribadi yang soméah, yakni selalu tampil menarik dengan wajah ramah dan murah senyum. Masyarakat Sunda juga memiliki selera humor yang tinggi. Kesimpulannya bahwa budaya soméah sebagai nilai kearifan lokal bertujuan untuk membangun dan menjaga hubungan berbasis budaya.
\end{abstract}

Kata-kata Kunci: brand personality; budaya; perilaku komunikasi; soméah; Sunda

\section{Soméah cultural values on communication behavior of Sundanese People}

\begin{abstract}
This research is based on the curiosity about soméah culture as a characteristic inherent in the Sundanese people. The research aims to find out specifically about the values of soméah culture, including the implications and applications of the communication behavior of the Sundanese people. To answer these objectives, researchers used data collection techniques through interviews and observations. Using a qualitative approach to the constructivist paradigm and ethnographic studies of public relations, studies that focus on cultural studies with the theory of public relations approach. The study found that soméah culture contained values of humility, politeness and friendliness. These values represent the brand personality of the Sundanese people. This is in harmony with their philosophy of life, namely Soméah Hade ka Sémah, which means friendly, kind, caring, entertaining and happy for everyone. The implications and application of life philosophy values are found in every communication behavior that occurs repeatedly in the internal and external environment. Communication behavior using the language of punten and mangga. Punten language means humility. While the use of the term mangga as a form of offer, invitation, invite and request. The results of this study also found that there are two aspects that proved the Sundanese are soméah people, namely always appear attractive with a friendly face and a smile. The Sundanese also have a high sense of humor. The conclusion is that soméah culture as a value of local wisdom aims to build and maintain cultural-based relationships.
\end{abstract}

Keywords: brand personality; communication behavior; culture; soméah; Sundanese

Korespondensi: Dr. Dasrun Hidayat, S.Sos., M.I.Kom. Universitas Bina Sarana Informatika, Jalan Sukalaksana Nomor 6 Antapani Bandung.Email: dasrun.dhy78@gmail.com 


\section{PENDAHULUAN}

Indonesia adalah negara yang majemuk karena terdiri dari beragam suku. Sensus penduduk tahun 2010 mencatat terdapat 1.331 (seribu tiga ratus tiga puluh satu) kategori suku, meliputi nama suku, sub-suku, nama sub dari sub-suku, hingga nama lain atau nama alias suatu suku (Tumoutounews, 2017). Suku adalah kelompok etnis dan budaya masyarakat yang terbentuk turun-temurun atau diwariskan pada generasi setelahnya. Lazimnya, identitas kesukuan melekat pada setiap orang sesuai suku bangsa kedua orang tuanya. Suku bangsa penduduk Indonesia mayoritas ditentukan mengikuti garis patrilineal atau garis kekerabatan ayah. Meski begitu, ada beberapa suku bangsa yang mengikuti garis matrilineal atau garis ibu, seperti Suku Minangkabau di Sumatera Barat, Suku Enggano di Bengkulu, Suku Petalangan di Riau, Suku Aneuk Jamee di Aceh, dan Suku Sakai di Riau. Sedangkan garis kekerabatan ayah, misalnya Suku Lampung, Suku Batak, dan termasuk Suku Sunda.

Bahasa merupakan salah satu faktor budaya yang mampu mendorong suatu suku populer atau dikenal oleh masyarakat. Hal ini terjadi karena bahasa dianggap sebagai parameter dalam mempelajari dan mengenalkan budaya kepada orang lain, termasuk berfungsi untuk memahami sekaligus membedakan antar budaya. Selaras dengan pernyataan Samovar bahwa bahasa sebagai alat untuk mengenal nilai budaya orang lain (Samovar, Porter, \& McDaniel, 2010). Selain itu, bahasa sebagai alat komunikasi juga dapat membentuk kelompokkelompok sosial tertentu. Bahasa digunakan sebagai alat interaksi di dalam lingkungan sosial karena bahasa dapat menjadi ruang bagi tumbuhnya nilai sosial, dimana terjadi interaksi antar manusia (Farady \& Sierjames, 2018). Misalnya, di dalam sebuah komunitas biasanya memiliki bahasa yang disepakati secara bersama. Bahkan melalui bahasa, tidak dapat dipungkiri bahwa masyarakat modern mampu lebih cepat menciptakan kelompok sosial budaya yang lebih beragam.

Pemaparan latar belakang pada paragraf sebelumnya merupakan alasan ketertarikan penulis untuk mengkaji secara khusus tentang nilai-nilai budaya di balik penggunaan istilah bahasa soméah yang direpresentasikan di setiap perilaku komunikasi masyarakat Suku
Sunda. Ketertarikan ini diperkuat pula ketika dilakukan survei dengan diberikan pertanyaan tentang karakteristik masyarakat Suku Sunda. Hasil survei menyebutkan bahwa masyarakat mengenal Suku Sunda sebagai masyarakat yang soméah yang direpresentasikan melalui penggunaan bahasa seperti punten dan mangga pada setiap perilaku komunikasi. Pendapat tersebut didasari oleh pengetahuan dan pengalaman selama berinteraksi yang mencerminkan pribadi terbuka, mudah bergaul dan menerima orang lain. Hal ini senada dengan filosofi hidup masyarakat Suku Sunda yaitu Soméah Hade ka Sémah, artinya ramah, bersikap baik, menjaga, menjamu dan membahagiakan setiap tamunya atau setiap orang meskipun belum dikenal (Hendriana \& Setiyadi, 2018). Masyarakat Suku Sunda sangat menjunjung tinggi nilai-nilai kesopanan, itulah kenapa Suku Sunda dikenal sebagai pribadi yang murah hati dan baik terhadap sesama, apalagi terhadap orang yang lebih tua.

Nilai-nilai budaya soméah sudah melekat dan mengkristal sebagai ciri khas, ikon sekaligus brand personality masyarakat Suku Sunda. Namun sayangnya, belum banyak yang mengetahui soméah sebagai brand personality Suku Sunda. Dalam studi tentang brand personality, Patterson, Khogeer, dan Hodgson dalam (R, Hanretty, \& Lettice, n.d., 2018) mengemukakan bahwa brand personality dibangun di atas konsep merek produk (product brand), akan tetapi konsep tersebut dapat juga digunakan sebagai karakter atau kepribadian seseorang dan sekelompok orang. Brand personality berangkat dari konsep merek (Kotsi \& Valek, 2017). Brand juga merepresentasikan gaya hidup serta status sosial kelompok masyarakat tertentu. Brand tidak hanya sekedar nama atau simbol yang melekat pada produk, akan tetapi brand memiliki enam tingkatan pengertian, yaitu atribut, manfaat, nilai, budaya, kepribadian dan pemakai (Purwaningwulan, 2017). Demikian pula halnya budaya soméah sebagai brand personalitiy yang dimiliki oleh masyarakat Suku Sunda. Budaya soméah diyakini mengandung nilai-nilai sekaligus ragam manfaat bagi pemilik budaya maupun masyarakat atau lingkungannya. Hal ini yang mendorong keyakinan mereka untuk senantiasa melestarikan budaya soméah sebagai brand personality masyarakat Suku Sunda.

Upaya memperkenalkan soméah sebagai 
brand personality salah satunya melalui tindakan personal branding. Menurut Wasesa, personal branding adalah kegiatan yang dimaksudkan untuk memperkenalkan seseorang kepada publik (Wasesa, 2011). Personal branding juga sebagai upaya untuk menarik minat masyarakat. Malaysia Tourism Promotion Board (MTPB) pernah melansir bahwa secara personal branding Malaysia mencitrakan dirinya sebagai bangsa multikultur (Alifahmi, 2012). Keberhasilan seseorang sebagai ikon karena adanya proses personal branding (Rezvanpour \& Bayat, 2017). Dalam konteks artikel ini, ikon sebagai personal branding masyarakat Suku Sunda adalah perilaku komunikasi soméah. Hal ini dapat ditemukan melalui perilaku komunikasi masyarakat Suku Sunda baik antar sesama maupun berbeda suku. Selain itu brand juga personal branding dapat dilalui dengan memanfaatkan media massa atau media sosial (Kusuma \& Sugandi, 2018), (Pakaradena et al., 2018).

Perilaku komunikasi secara tidak langsung sebenarnya mampu merepresentasikan nilainilai budaya soméah masyarakat Suku Sunda. Namun, hal ini membutuhkan kesungguhan dalam memberikan pemahaman kepada publik terhadap pesan komunikasi. Dalam konteks penelitian ini adalah pesan tentang nilai-nilai budaya soméah masyarakat Suku Sunda. Pesan yang disampaikan melalui perilaku komuikasi sangat mungkin dinilai masyarakat positif karena terpenuhinya pengetahuan dan pemahaman terhadap budaya soméah. Adanya respons positif melalui penilaian diharapkan mampu membangun citra (image) tentang budaya soméah. Citra adalah kesan yang sengaja diciptakan terhadap suatu objek. Lau \& Phau mendefinisikan citra sebagai bentuk keyakinan yang dipegang oleh masyarakat (Amron, 2018). Citra sebuah persepsi dan keyakinan yang dimiliki oleh setiap orang terhadap objek yang diterima oleh panca indra. Citra dapat berupa persepsi positif maupun negatif terhadap perilaku komunikasi yang melekat pada kelompok masyarakat tertentu (Hidayat et al., 2017).

Masyarakat Suku Sunda yang dikenal soméah juga direpresentasikan melalui pribadi yang humoris. Mereka dikenal sebagai pribadi yang hidup dengan selera humor tinggi. Gaya humor yang dibingkai di dalam setiap perilaku komunikasi tersebut tidak heran apabila membuat orang lain tertawa terbahak-bahak. Selain kepiawaian dalam menyusun ide juga pandai dalam menyampaikan ide dengan gaya yang khas dan unik. Misalnya, kekhasan bahasa, dialek bahkan dalam pelafalan huruf seperti "F" yang selalu tertukar dengan huruf "P" atau pelafalan huruf " $D$ " menjadi " $T$ ". Hal ini seringkali mengundang rasa geli sehingga membuat orang lain tertawa. Karakter masyarakat Suku Sunda dengan selera humor yang tinggi juga sangat melekat di benak masyarakat. Tidak mengenal usia, pendidikan maupun jabatan, selera humor ini senantiasa ditemukan pada setiap perilaku komunikasi.

Berdasarkan pemaparan permasalahan pada bagian pendahuluan, maka pada artikel ini penulis tertarik untuk mengkaji lebih dalam tentang implikasi dan aplikasi nilai-nilai budaya soméah sebagai brand personality masyarakat Suku Sunda, dan upaya memperkenalkan budaya soméah kepada masyarakat melalui personal branding. Penelitian ini bertujuan untuk mengetahui secara spesifik tentang nilai-nilai budaya soméah termasuk implikasi dan aplikasinya pada perilaku komunikasi masyarakat Suku Sunda.

\section{METODE PENELITIAN}

Penelitian ini termasuk pada kajian budaya dengan pendekatan teori public relations atau penulis menyebutnya degan istilah public relations budaya, yakni sebuah kajian yang bertujuan memahami perilaku komunikasi untuk membangun hubungan. Berdasarkan aspek aksiologis tersebut, maka penelitian ini secara epistimologis memilih etnografi public relations sebagai studi dengan pendekatan kualitatif konstruktif. Studi etnografi public relations menekankan pada komponen strategi komunikasi di dalam aktivitas komunikasi meliputi Insight, Program Strategic, Program Implementation, Action and Reputation yang disingkat menjadi IPPAR Model (Hidayat, Kuswarno, Zubair, \& Hafiar, 2018).

Insight dapat dikategorikan sebagai tahapan awal dalam memetakan realitas atau fenomena. Tahapan ini dapat pula disebut sebagai kegiatan analisis situasi (Hidayat \& Suhartini, 2018). Insight bertujuan untuk memahami situasi yang melatar belakangi aktivitas komunikasi berbasis budaya. Yang dimaksud Insight pada penelitian ini yaitu melakukan analisis 
Tabel 1 IPPAR Model

\begin{tabular}{|c|c|c|}
\hline IPPAR & Definisi & Penjelasan \\
\hline I- Insight & $\begin{array}{l}\text { - Berkenaan dengan analisis situasi, } \\
\text { pengumpulan data terkait dengan } \\
\text { aktivitas komunikasi budaya. } \\
\text { - Waktu dan tempat aktivitas } \\
\text { komunikasi budaya berlangsung, } \\
\text { situasi psikologis pembicaraan, } \\
\text { sasaran kegiatan, audience. } \\
\text { - Merujuk pada pihak-pihak yang } \\
\text { terlibat dalam aktivitas komunikasi } \\
\text { budaya. }\end{array}$ & $\begin{array}{l}\text { - Analisis situasi berkaitan } \\
\text { dengan persiapan pada setiap } \\
\text { aktivitas komunikasi budaya. } \\
\text { - Menekankan pada situasi fisik } \\
\text { dan psikologis, tempat, audience } \\
\text { atau pihak terkait dalam } \\
\text { aktivitas komunikasi budaya. } \\
\text { Misal, pembicaraan pada } \\
\text { musyawarah mufakat, mufakat } \\
\text { adat berbeda dengan obrolan } \\
\text { sehari-hari, mulai dari setting } \\
\text { waktu, tempat dan pihak yang } \\
\text { terlibat di dalam kegiatan. }\end{array}$ \\
\hline $\mathrm{P}$ - Program Strategic & $\begin{array}{l}\text { - Berkaitan dengan jenis kegiatan, } \\
\text { tema, pesan budaya yang akan } \\
\text { disampaikan. } \\
\text { - Mengacu bentuk pesan berkenaan } \\
\text { dengan kata yang digunakan, } \\
\text { bagaimana penggunaannya. } \\
\text { - Isi pesan berkenaan dengan } \\
\text { hubungan antara apa yang dikatakan } \\
\text { dengan topik pembicaraan. }\end{array}$ & $\begin{array}{l}\text { - Kegiatan komunikasi budaya } \\
\text { mempengaruhi strategi kegiatan } \\
\text { berupa jenis, bentuk dan isi } \\
\text { pesan. } \\
\text { - Misalnya kegiatan upacara } \\
\text { adat pernikahan tentu saja } \\
\text { berbeda isi pesan dan topik } \\
\text { pembicaraannya dengan } \\
\text { percakapan biasa. }\end{array}$ \\
\hline $\begin{array}{l}\mathrm{P} \text { - Program } \\
\text { Implementation }\end{array}$ & $\begin{array}{l}\text { - Berkenaan dengan pelaksanaan } \\
\text { aktivitas komunikasi budaya. } \\
\text { - Mengacu pada nada, cara, dan } \\
\text { semangat di mana suatu pesan } \\
\text { disampaikan. } \\
\text { - Mengacu pada jalur bahasa yang } \\
\text { digunakan dan juga mengacu pada } \\
\text { kode ujaran yang digunakan. } \\
\text { - Mengacu pada norma atau aturan } \\
\text { dalam berinteraksi dan juga mengacu } \\
\text { pada penafsiran terhadap ujaran dari } \\
\text { lawan bicara. } \\
\text { - Mengacu pada jenis bentuk } \\
\text { penyampaian }\end{array}$ & $\begin{array}{l}\text { - Dengan senang hati, dengan } \\
\text { serius, dengan singkat, dengan } \\
\text { sombong, dengan mengejek } \\
\text { dan sebagainya. Atau dapat } \\
\text { ditunjukkan juga dengan gerak } \\
\text { tubuh dan isyarat. } \\
\text { - Jalur tulisan, lisan, melalui } \\
\text { telegraf atau telepon, bahasa, } \\
\text { dialek, ragam atau register. } \\
\text { - Berhubungan dengan cara } \\
\text { berinterupsi, cara bertanya, dan } \\
\text { sebagainya. } \\
\text { - Narasi; puisi, pepatah, doa, } \\
\text { dan sebagainya. }\end{array}$ \\
\hline $\mathrm{A}-$ Action & $\begin{array}{l}\text { - Audit persepsi publik. } \\
\text { - Penilaian, respons publik. }\end{array}$ & $\begin{array}{l}\text { - Penilaian publik terhadap } \\
\text { aktivitas komunikasi berupa } \\
\text { citra budaya atas relasi budaya } \\
\text { yang terbangun. }\end{array}$ \\
\hline $\mathrm{R}$ - Reputation & $\begin{array}{l}\text { - Kepercayaan dan dukungan publik } \\
\text { terkait dengan sekumpulan citra } \\
\text { tentang relasi budaya. }\end{array}$ & $\begin{array}{l}\text { - Hasil akhir dari aktivitas } \\
\text { komunikasi; membangun } \\
\text { dukungan publik sehingga } \\
\text { terbangun pola relasi budaya. }\end{array}$ \\
\hline
\end{tabular}

Sumber: (Hidayat et al., 2018) 
terhadap perilaku komunikasi masyarakat Suku Sunda yang dikenal soméah. Insight juga dimaksudkan untuk menetapkan setting publik atau masyarakat yang terlibat di dalam aktivitas komunikasi berbasis budaya atau komunikasi budaya. Keterlibatan mereka harus relevan dengan tujuan utama kegiatan.

Aspek lain yang perlu diperhatikan dalam aktivitas komunikasi budaya yaitu perencanaan aktivitas atau program strategic yang meliputi jenis kegiatan, bentuk kegiatan, tema, isi pesan, strategi penyampaian pesan, dan media yang digunakan (Hidayat \& Suhartini, 2018). Hadirnya media sebagai medium atau ruang virtual bagi sejumlah pengguna dari seluruh penjuru daerah untuk menyatukan pikiran, memberikan pandangan, melakukan kritik, dan menyampaikan opini (Mendayun \& Sjuchro, 2018). Tahapan ini memastikan bahwa perilaku komunikasi soméah hanya terdapat pada aktivitas tertentu atau pada setiap aktivitas masyarakat Suku Sunda baik dengan sesama maupun antar suku yang ada di lingkungannya.

Aspek lain yang dianalisis dalam aktivitas komunikasi berbasis budaya yaitu memastikan aktivitas yang sudah dirancang dapat dilaksanakan atau program implementation. Langkah ini bertujuan menjalankan semua aktivitas komunikasi budaya sesuai dengan aturan atau ketentuan yang telah ditetapkan. Tahapan ini juga merujuk pada proses kontrol dan evaluasi terhadap pelaksanaan kegiatan komunikasi meliputi nada dalam berbicara, cara bertutur, bahasa, perilaku dan etika dalam menyampaikan pesan (Hidayat \& Suhartini, 2018). Pada tahapan ini tidak sekedar mengetahui fase-fase dari perilaku komunikasi, akan tetapi kaidah dan keyakinan masyarakat Suku Sunda terhadap perilaku komunikasi budaya soméah. Hal ini bertujuan untuk mengukur penilaian publik (action) melalui evaluasi kegiatan sehingga diketahui respons publik sebagai tolak ukur reputasi (reputation) masyarakat Suku Sunda yang dikenal soméah.

IPPAR Model sebagai rumus analisis data etnografi public relations mengacu pada rumus analisis data etnografi komunikasi Dell Hymes. Rumus yang dimaksud yakni SPEAKING meliputi Situation, Participants, Ends, Act Sequences, Key, Instumentalitis, Norms dan Genres (Ray \& Biswas, 2011). Namun yang membedakan terdapat pada hasil akhir bahwa etnografi public relations tidak sekedar mengetahui setting dan fase dari perilaku komunikasi, akan tetapi mengkaji bahwa perilaku tersebut tetap dipertahankan karena memiliki keyakinan dan tujuan bersama yakni untuk membangun dan mengelola hubungan berbasis budaya.

Teknik pengumpulan data etnografi public relations tidak berbeda dengan etnografi komunikasi karena keduanya memiliki kesamaan pada fokus kajian yaitu perilaku komunikasi. Kesamaan ini terjadi karena etnografi komunikasi masih sangat cair dan terbuka, sehingga dapat diterapkan pula pada metode lainnya. Etnografi komunikasi menekankan pada langkah introspeksi, tindakan ini dilakukan ketika peneliti meneliti kebudayaannya sendiri sehingga diperlukan upaya mengoreksi diri sendiri atau mencoba melepaskan diri dari objek yang sedang diteliti (Kuswarno, 2008).

Selanjutnya melakukan observasi, wawancara dan analisis dokumen. Demikian halnya dengan teknik pengumpulan data pada etnografi public relations. Pengumpulan data menekankan pada teknik yang biasanya digunakan pada etnografi komunikasi. Teknik data melalui observasi partisipan atau melakukan pencarian data secara langsung atau on the spot data. Berpartisipasi artinya peneliti berada di dalam masalah penelitian dengan melibatkan diri pada aktivitas masyarakat Suku Sunda atau informan penelitian yang ada di kota Bandung. Pada penelitian ini, peneliti menjadi bagian dari mereka. Ikut serta dalam aktivitas keseharian masyarakat Suku Sunda yang sekaligus diposisikan sebagai informan. Data etnografi bersifat alami sehingga peneliti sebagai etnografer dituntut untuk pandai dalam memainkan peran di lapangan sebagai partisipan. Peneliti juga melakukan observasi tanpa ada keterlibatan secara langsung atau tanpa partisipasi. Tahapan mencari data dilakukan tanpa adanya keterlibatan peneliti di dalam kelompok masyarakat Sunda yang sedang diteliti.

Pengumpulan data juga menggunakan teknik wawancara mendalam yakni metode riset dengan menggunakan wawancara tatap muka. Wawancara mendalam akan menghasilkan data secara terperinci dan sistematis. Peneliti pada penelitian etnografi public relations seyogyanya memahami konsep tentang budaya dan public relations sekaligus sebagai objek 
kajian penelitian. Hal ini dapat mempermudah peneliti dalam memetakan pertanyaan wawancara. Dalam konteks penelitian ini, penulis melibatkan beberapa masyarakat Suku Sunda beserta pemerhati budaya.

Prinsip autentisitas data etnografi public relations sama dengan etnografi komunikasi. Autentisitas atau teknik keabsahan data etnografi public relations mengacu pada teknik yang dikemukan oleh Moleong dalam Kuswarno. Teknik tersebut meliputi perpanjangan keikutsertaan, ketekunan, triangulasi, analisis kasus negatif, dan menyediakan referensi relevan (Kuswarno, 2008). Teknik keabsahan data bertujuan untuk mendapatkan autentisitas data. Langkah peneliti pada penelitian ini meliputi (a) perpanjangan keikutsertaan peneliti dalam aktivitas kelompok masyarakat Suku Sunda. (b) Ketekunan pengamatan, yaitu upaya yang cermat untuk menemukan ciri-ciri, dan unsur-unsur dalam situasi yang relevan dengan masalah penelitian tentang nilai budaya soméah. (c) Triangulasi. Cross-check data dengan memperhatikan tiga unsur yaitu metode, waktu dan sumber data. (e) Review, artinya melakukan audit data melalui pemeriksaan terhadap seluruh data mulai dari data mentah pada data hasil reduksi, deskripsi, dan analisis yang diperoleh peneliti selama melakukan wawancara dan observasi pada setiap aktivitas masyarakat Suku Sunda di kota Bandung.

Persamaan secara aplikatif lainnya antara etnografi public relations dengan etnografi komunikasi terdapat pada teknik analisis data. Metode etnografi public relations menggunakan teknik analisis data yang umum digunakan pada metode etnografi komunikasi. Teknik analisis data meliputi reduksi, deskripsi, dan analisis atau interpretasi data. Tahapan reduksi adalah tahapan peneliti mengolah data dengan membuat transkrip hasil wawancara maupun transkrip atas catatan hasil observasi terhadap aktivitas komunikasi masyarakat Suku Sunda. Tahapan berikutnya membuat deskripsi data berupa display atau membuat kategorisasi data. Memilih dan memilah serta memetakan data dengan membuat masing-masing tema hasil data penelitian berdasarkan tema penelitian tentang budaya soméah. Display data juga bertujuan untuk memetakan data berdasarkan sub-sub tema temuan penelitian yang akan menjawab masing-masing dari pertanyaan penelitian. Tahapan selanjutnya peneliti menuliskan beberapa data penting atau melakukan highlight data yang dapat menjawab tujuan penelitian. Data akurat yang diambil dari data display berupa tabel, grafik, diagram, model yang dapat menggambarkan objek penelitian. Pada tahapan ini peneliti memetakan aspek-aspek penting yang berhubungan dengan sub tema temuan penelitian.

Hasil highlight data pada penelitian ini selanjutnya dideskripsikan di setiap sub-bab hasil penelitian. Deskripsi high light data dituangkan melalui tiga point utama. Point pertama pemaparan prolog yang berkaitan dengan data yang akan disampaikan. Point kedua memaparkan data lapangan berupa kutipan langsung pernyataan informan yang sudah direduksi. Point ketiga memberikan deskripsi atas highlight data atau kutipan pernyataan informan. Proses deskripsi highlight data disebut pula sebagai langkah konstruk derajat ke-dua.

Tahapan analisis data berikutnya adalah melakukan konstruk derajat ketiga. Langkah yang dilakukan oleh peneliti yaitu menginterpretasi data. Pada tahapan ini peneliti melakukan analisis, teorisasi data atau mengkonfirmasi data berdasarkan teori yang relevan. Interpretasi dapat dilakukan melalui triangulasi data berdasarkan teori yang dimaksudkan untuk memperkuat temuan atau menolak hasil penelitian. Triangulasi juga dapat berupa konfirmasi data berdasarkan sumber informan, waktu, dan teknik pengumpulan data. Pada sumber lain tahapan konstuk drajat ke-tiga disebut pula sebagai langkah penarikan kesimpulan atau conclusing drawing. Tahapan terakhir yang harus dilakukan oleh peneliti dengan melakukan analisis data hasil penelitian berdasarkan teori-teori relevan.

Penentuan informan sebagai subjek atau sumber data pada studi etnografi public relations, ditentukan dengan cara yang lazim digunakan pada penelitian kualitatif yaitu secara purposive. Teknik ini menekankan pada kriteria calon informan yang ditentukan berdasarkan kebutuhan penelitian. Purposive sampling sangat membantu dan memudahkan peneliti dalam memenuhi informan sebagai sumber data. Adapun informan pada penelitian ini yaitu masyarakat Suku Sunda yang berdomisili di Kota Bandung. Mereka tersebar di beberapa lokasi yaitu Bandung Utara, Selatan, Barat dan Timur. 


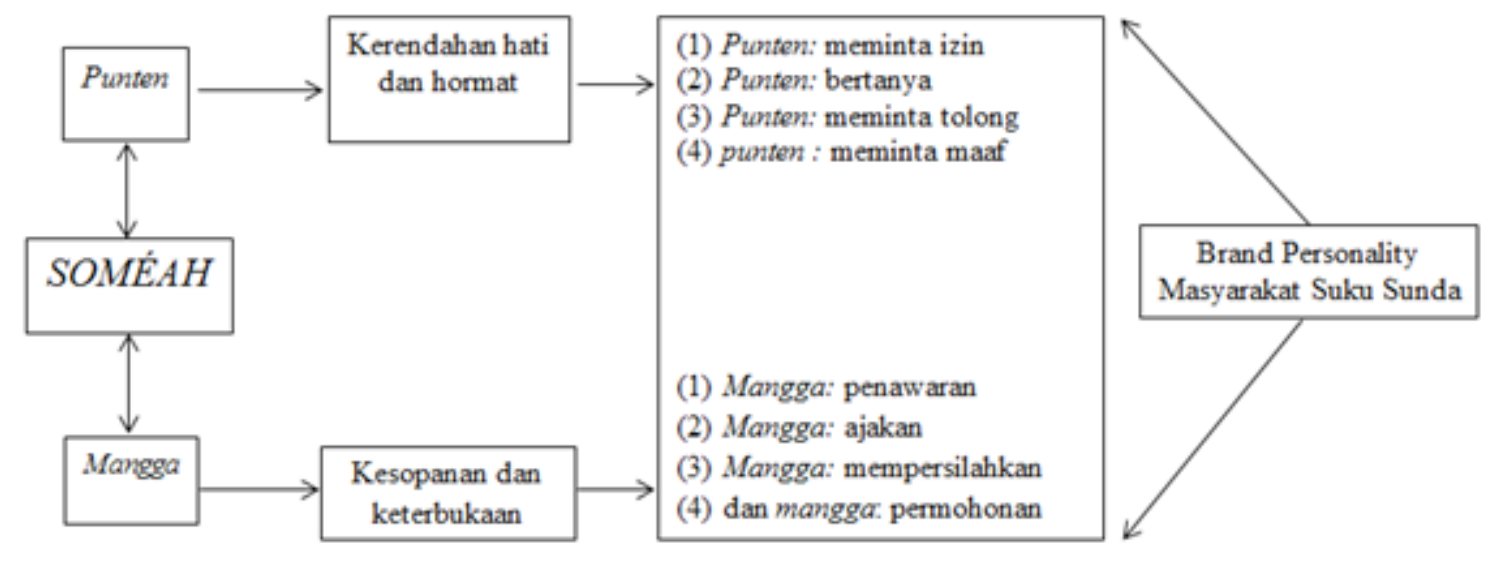

Sumber: Hasil Penelitian, 2018

Gambar 1 Nilai Budaya Soméah sebagai Brand Personality Suku Sunda

\section{HASIL DAN PEMBAHASAN}

Budaya soméah merepresentasikan brand personality masyarakat Suku Sunda. Soméah mengandung nilai-nilai kepribadian masyarakat Suku Sunda seperti ramah, sopan, dan terbuka. Nilai-nilai tersebut ditransformasikan melalui perilaku komunikasi sehari-hari di lingkungan sekitar yang terjadi secara terencana dan berulang. Perilaku komunikasi tersebut seakanakan sudah menjadi kebiasaan dan mengkristal di dalam pribadi setiap anggota masyarakat Suku Sunda. Perilaku komunikasi soméah tersebut telah terpolakan sehingga membangun relasi budaya atau hubungan yang dilandasi oleh nilai-nilai budaya setempat. Relasi budaya menjadi bukti kekuatan dan dukungan masyarakat Suku Sunda dalam mengenalkan dan membangun pemahaman tentang soméah sebagai brand personality.

Upaya memperkenalkan budaya soméah sebagai brand personality dapat disebut pula dengan istilah kegiatan personal branding, yaitu kegiatan yang bertujuan untuk memperkenalkan seseorang atau sekelompok orang. Demikian pula dengan budaya soméah dibangun bertujuan untuk memperkenalkan nilai budaya masyarakat Suku Sunda sebagai kelompok masyarakat yang rendah hati, sopan, ramah dan terbuka. Nilai-nilai tersebut direpresentasikan melalui perilaku komunikasi dalam penggunaan bahasa pada pesan komunikasi seperti pesan punten dan mangga. Pesan ini selalu disampaikan di setiap konteks komunikasi. Punten mengandung makna kerendahan hati dan hormat. Sedangkan penggunaan istilah mangga mencerminkan kesopanan dan keterbukaan. Ucapan mangga sering kali diaplikasikan pada konteks memberikan penawaran, ajakan, mempersilahkan dan permohonan.

Hasil penelitian ini juga menemukan bahwa terdapat dua (2) aspek yang membuktikan bahwa masyarakat Suku Sunda merupakan pribadi yang soméah, yakni selalu tampil menarik (good looking) dengan wajah ramah dan murah senyum. Aspek lain yang memperkuat budaya soméah yakni masyarakat Suku Sunda juga memiliki selera humor yang tinggi. Berdasarkan hasil pengamatan, selera humor yang dimiliki membuat mereka mudah untuk bergaul tanpa terkecuali dengan masyarakat non Suku Sunda yang tinggal di sekitar mereka. Berikut ini digambarkan tentang nilai-nilai yang terkandung di dalam budaya soméah yang menjadi bagian dari brand personality masyarakat Suku Sunda.

Suku Sunda merupakan kelompok masyarakat yang konsisten dalam melestarikan nilai-nilai yang diyakini memiliki manfaat. Kosep keyakinan terhadap nilai budaya setempat merupakan bagian dari kearifan lokal. Soméah merupakan salah satu nilai kearifan lokal masyarakat Suku Sunda yang senantiasa dipertahankan. Kata soméah dapat diartikan sebagai ramah, sopan dan terbuka. Perilaku soméah diinternalisasikan dan disepakati sebagai tatanan berperilaku atau pedoman atau tuntunan yang bersifat organik. Tidak diketahui secara pasti sejarah kapan pertama kali pesan soméah diucapkan pada saat berkomunikasi. Namun, pesan ini disampaikan di setiap konteks komunikasi bahkan telah menjadi brand atau identitas tersendiri bagi kelompok masyarakat 
Suku Sunda.

Budaya soméah masyarakat Suku Sunda dapat dikatakan berbeda dengan suku lainnya. Hal ini dapat dijumpai pada perilaku komunikasi yang memperlihatkan tingkat kesopanan yang relatif tinggi. Misalnya, penggunaan istilah atau menyisipkan kata punten dan mangga yang selalu ada di setiap perilaku komunikasi. Ungkapankata punten dan mangga tersebut dapat dimaknai sebagai bentuk sopan santun, hormat dan keterbukaan terhadap orang lain termasuk orang yang baru dikenal. Substansi penggunaan bahasa verbal seperti ungkapan punten dan mangga, selaras dengan pendapat Suranto, bahwa pesan verbal dapat mencerminkan drajat tata krama berbahasa (Suranto, 2010). Proses komunikasi verbal adalah kegiatan interaksi penyampaian dan penerimaan pesan-pesan yang dilakukan melalui percakapan (lisan) dan tulisan. Bahasa merupakan bagian terpenting dalam mengemas pesan komunikasi. Seringkali proses komunikasi mengalami kendala karena makna pesan dipahami oleh orang-orang yang berbeda budaya. Dari hasil pengamatan, pesan verbal dengan kata punten menjadi fenomena baru bagi orang yang belum mengenal budaya Suku Sunda. Ketidaktahuan tersebut justru menimbulkan persepsi yang beragam. Namun seiring dengan perjalanan waktu, orang yang bermaksud untuk menetap di wilayah Jawa Barat akan mengalami proses belajar terhadap budaya baru tersebut. Proses yang menuntun pengetahuan dan penerimaan budaya soméah masyarakat Suku Sunda.

Kata punten secara bahasa diartikan sebagai kata maaf. Kata maaf sebagai wujud kerendahan hati biasanya dipegang kuat oleh kelompok masyarakat yang meyakini pola budaya konteks tinggi (high context culture). Pola ini sering dijumpai di Indonesia sebagai masyarakat yang tetap menjunjung budaya, termasuk kelompok masyarakat Suku Sunda. Budaya tingkat tinggi ditandai adanya tata kelakuan yang disertai oleh perilaku dan rasa saling menghormati, simpati dan empati (Samovar et al., 2010). Soméah dapat menjadi parameter budaya tingkat tinggi di Indonesia. Masyarakat Suku Sunda sangat menjunjung tata kelakuan sebelum bertindak. Mengutamakan atribut yang terlihat dan terukur dibandingkan yang tidak tampak. Bahkan budaya tingkat tinggi juga dapat diartikan sebagai budaya basa-basi sebelum bertindak.

Implementasi bentuk pesan verbal punten muncul hampir di setiap konteks komunikasi antara sesama Suku Sunda maupun dengan masyarakat yang ada disekitarnya. Dari hasil pengamatan, adapun bentuk aplikasi bahasa verbal punten antara lain, (1) punten disampaikan pada saat akan meminta izin berjalan dan melintas di depan orang lain. "punten kapayunan" artinya "maaf saya duluan" ketika konteksnya ingin mendahului orang lain. "punten bade ngalangkung" permisi untuk meminta izin melewati orang yang sedang berada disekitar jalan tersebut. (2) punten juga ditemukan pada saat akan bertanya kepada orang lain. "punten bade tumaros" artinya "saya meminta izin untuk bertanya" (3) punten seringkali juga diucapkan untuk meminta tolong seperti "punten nyuhunkeun tulung". (4) punten untuk meminta maaf, "punten abdi nu lepat" (maaf saya yang bersalah). Ketika kita merasa melakukan kesalahan yang disengaja ataupun tidak, kita dapat mengungkapkan permohonan maaf tersebut dengan menggunakan kata punten. Kata punten yang selalu mengiringi perilaku komunikasi mengandung nilai kerendahan hati dan rasa hormat. Konteks komunikasi dengan menggunakan kata punten dapat dikategorikan sebagai komunikasi verbal. Bahasa verbal sebagai wujud budaya yang sifatnya tidak berwujud atau abstrak. Sedangkan wujud budaya yang berwujud dan dapat dilihat oleh panca indra seperti artefak berupa kerajinan, bangunan dan lainnya (Leuape, 2017).

Implikasi penggunaan bahasa Sunda punten sebagai bentuk kerendahan hati, juga diperkuat adanya temuan bahwa pengucapan punten senantiasa disertai dengan membungkukkan badan. Hal ini menekankan bahwa pengucapan pesan punten secara verbal diikuti pula dengan pesan nonverbal. Pesan nonverbal berfungsi untuk memperkuat pesan verbal. Pesan nonverbal sering pula disebut bahasa tubuh atau bahasa isyarat. Tubb dan Carter mendefinisikan pesan nonverbal sebagai pesan yang tidak diucapkan secara lisan maupun tertulis (Suranto, 2010). Pesan nonverbal juga dapat diartikan sebagai penciptaan dan pertukaran pesan dengan tidak menggunakan kata-kata, melainkan menggunakan bahasa isyarat seperti gerakan tubuh, sikap tubuh, vokal yang bukan kata-kata, kontak mata, ekspresi muka, kedekatan jarak, sentuhan, dan sebagainya (Suranto, 2010). Bahasa adalah simbol dan diantaranya terdapat simbol bahasa nonverbal. 
Budaya didasarkan pada simbol (Samovar et al., 2010). Simbol budaya dapat dalam bentuk gerakan, pakaian, objek, bendera, ikon keagamaan, dan sebagainya. Walaupun semua budaya menggunakan simbol untuk berbagai fakta, suatu fakta dan simbol yang digunakan terkadang berbeda. Pesan nonverbal yang ditemukan pada konteks pesan komunikasi punten berupa gerakan tubuh (gesture). Selain itu dijumpai pula pesan nonverbal ekspresi muka dengan muka tersenyum seiring mengucapkan kata punten.

Penilaian bahwa masyarakat Suku Sunda sebagai kelompok masyarakat yang ramah dan menjunjung tinggi sopan santun juga dapat diukur dari penggunaan pesan verbal mangga. Pesan ini diucapkan ketika memberikan penawaran dan mempersilahkan seseorang. Misalnya, mangga calik heula (silahkan duduk dulu). Mangga sindang heula (silahkan, ayo mampir dulu). Mangga kalebeutheula (silahkan masuk dulu). Mangga dileuet (silahkan dimakan) dan lainnya. Pesan komunikasi mangga ini selalu menyertai awal komunikasi dengan maksud mempersilahkan dan menawarkan. Sama halnya dengan pesan punten, pesan mangga juga mengandung nilai kearifan lokal. Punteun dan mangga sebagai nilai budaya soméah senantiasa dipertahankan karena dasar keyakinan (Cromer, Gray, Vasquez, \& Freyd, 2018). Nilai lokal yang terdapat pada budaya soméah yakni berupa tata kelakuan yang menekankan pada etika dan tata krama yang dimiliki oleh setiap pribadi masyarakat Suku Sunda.

Kebiasaan masyarakat Suku Sunda dengan mengucapkan kata punten dan mangga di setiap konteks komunikasi sebenarnya dapat dijumpai pula di suku-suku lainnya. Namun, cara penyampaiannya yang berbeda, mulai dari penggunaan bahasa hingga dialeknya. Misalnya, masyarakat Suku Saibatin di Lampung, menggunakan istilah mahapyu atau tabikpuuun, artinya permohonan maaf sebelum bertindak. Seiring dengan mengucapkan kata tersebut kedua belah tangannya ditempelkan di dada sambil menganggukkan kepala. Fenomena ini membuktikan bahwa setiap kelompok masyarakat memiliki kode berbicara yang berbeda. Gerry Philipsen dalam teorinya speech codes theory menjelaskan bahwa kode berbicara dapat dijumpai berupa aksen, dialek bahkan bahasa (Griffin, 2008). Demikian pula halnya dengan pesan komunikasi punten dan mangga, mencerminkan bahwa masyarakat Suku Sunda memiliki perbedaan dalam kode berbicara. Kode psikologi menjelaskan bahwa Suku Sunda sangat lembut dan sensitif sehingga gaya berkomunikasi menggunakan kode berbicara yang lemah -lembut dengan power suara yang rendah. Kondisi psikologi ini berlawanan dangan suku-suku yang ada di Pulau Sumatera. Misalnya Suku Lampung yang dikenal dengan gaya berbicaranya tegas dan menggunakan power yang tinggi. Perbedaan dalam penggunaan dan penyampaian bahasa merepresentasikan drajat tata krama (Suranto, 2010). Sedangkan secara sosiologi juga mempengaruhi gaya berbicara Suku Sunda yang gemar berkelompok atau bersama-sama secara kolektif. Sangat menghargai kebersamaan dan memperhatikan faktor kedekatan secara kekerabatan maupun kedekatan emosional. Secara retorik gaya berbicara masyarakat Suku Sunda sangat persuasif. Kepiawaian dalam merangkai kata dan kelembutan dalam menyampaikannya membuat orang lain mudah untuk dipengaruhi dan diajak. Dalam teori paradigma naratif komunikasi persuasif dibangun salah satunya karena kepandaian dalam menyampaikan pesan dengan gaya bertutur atau bercerita (Griffin, 2008). Hal ini ditemukan pada strategi komunikasi masyarakat Suku Sunda dengan simbol dan kode berbicara yang menekankan pada nilai-nilai soméah.

Ada beberapa hal yang diperhatikan dalam strategi komunikasi masyarakat Suku Sunda sebelum bertindak. Tindakan didasarkan pada pertimbangan, analisis terhadap situasi sebelum bertindak (insight). Aspek ini memperhatikan tujuan dan sasaran aktivitas komunikasi. Misalnya, sebelum melakukan komunikasi senantiasa memperhitungkan lawan berbicara. Hal ini menjadi pertimbangan awal karena sangat berkaitan dengan gaya komunikasi yang akan digunakan. Sebut saja gaya komunikasi dengan pendekatan persuasif. Komunikasi persuasif dimaksudkan untuk memengaruhi orang lain yang notabene berbeda budaya (Samovar et al., 2010). Hasil penelitian menemukan bahwa perilaku komunikasi soméah ditujukan kepada semua orang tidak terkecuali pada orang yang baru dikenal. Masyarakat Suku Sunda memperlakukan orang lain dengan ramah dan sopan. Mereka dalam berkomunikasi sangat memperhitungkan nilai-nilai budaya soméah. 
Nilai tersebut diimplementasikan melalui perilaku komunikasi dengan menggunakan kata-kata yang santun seperti pesan punten dan mangga. Temua ini sekaligus memperkuat aspek lain dari strategi komunikasi yaitu membuat perencanaan aktivitas komunikasi atau disebut program strategic. Aspek ini meliputi perencanaan jenis dan bentuk aktivitas, pesandan cara menyampaikan pesan komunikasi. Tindak komunikasi dengan dilandasi oleh perencanaan sangat membantu dalam pencapaian tujuan komunikasi. Demikian halnya dengan tindak komunikasi berbasis budaya soméah. Tindakan ini ditandai dengan nada yang sopan dan ramah sebagai cara berkomunikasi persuasif. Cara ini berdampak terhadap penilaian publik bahwa masyarakat Suku Sunda memiliki karakter yang ramah dan rendah hati. Hal ini diperkuat pula oleh pengakuan informan bahwa mereka memiliki falsafah hidup yaitu Soméah Hade ka Sémah. Falsafah yang menggambarkan tentang sikap ramah dan rendah hati. Sikap tersebut dapat diukur melalui konsistensi dalam menjunjung tinggi nilai kebersamaan dan kesopanan. Sikap atau karakter ini pula yang menjadi aspek personal branding bahwa orang Sunda dikenal murah hati dan baik terhadap sesama apalagi terhadap orang yang lebih tua ataupun belum dikenal.

Penilaian tentang karakter soméah pada masyarakat Suku Sunda juga dapat diartikan sebagai bentuk dukungan dan kepercayaan masyarakat. Dukungan tersebut mampu mendorong terciptanya hubungan di lingkungan internal Suku Sunda maupun di lingkungan eksternal. Penilaian publik dalam istilah ilmu public relations disebut citra dan reputasi. Citra merupakan sekumpulan penilaian publik terhadap perilaku masyarakat Suku Sunda yang merepresentasikan reputasi budaya. Citra adalah bagian dari reputasi (Alifahmi, 2012). Sedangkan reputasi dapat diartikan sebagai rekam jejak atau deretan citra yang terbangun dalam waktu yang cukup lama. Reputasi Suku Sunda sampai saat ini tetap dikenal sebagai kelompok masyarakat yang mengedepankan hubungan dibandingkan tujuan. Hubungan menjadi segalanya karena hubungan dinilai sebagai wujud dari proses membangun dan menjaga kepercayaan publik.

Soméah sebagai nilai budaya lokal terintegrasi dalam sistem masyarakat Suku Sunda dengan suku lainnya. Soméah dipelajari dan dipraktikkan sebagai suatu kesatuan yang utuh dan saling berhubungan dengan sistem kepribadian masyarakat Suku Sunda dengan suku lainnya. Soméah sebagai salah satu alasan orang lain merasa nyaman tinggal bersama di lingkungan kelompok masyarakat Suku Sunda. Hidup berdampingan bahkan tidak sedikit terjadi integrasi budaya melalui pernikahan antarbudaya. Pernikahan ini sekaligus memperkuat keberadaan nilai-nilai budaya masyarakat Suku Sunda. Adanya penerimaan dan pengakuan mendorong terbangunnya relasi budaya atau hubungan yang dilandasi oleh penerimaan budaya.

Relasi budaya merupakan hasil dari kajian budayayangmempertemukankonsepbudayadan teori public relations. Relasi budaya terbentuk karena adanya kekhasan dan konsistensi tindak komunikasi yang dilandasi oleh nilai-nilai budaya. Relasi budaya juga mengacu pada tujuan utama dalam mempelajari ilmu public relations yaitu memahami perilaku komunikasi sebagai upaya membangun hubungan di dalam kelompok tertentu (Sriramesh \& Vercic, 2003). Penekanan relasi budaya pada komunikasi dan hubungan. Adanya hubungan karena perilaku komunikasi yang dapat dipahami dan terima oleh orang lain. Public relations tidak hanya mengetahui perilaku komunikasi, akan tetapi mencoba memahami konsistensi perilaku komunikasi sebagai wujud keyakinan terhadap warisan budaya yang berkesinambungan. Diantara penelitian yang mengungkapkan tentang relasi budaya di Indonesia adalah penelitian mengenai nilai budaya musyawarah mufakat (Kriyantono \& Mckenna, 2017). Kriyantono memaparkan bahwa ada keterkaitan nilai-nilai budaya di Indonesia dengan teori public relations. Budaya dapat bertahan karena adanya keyakinan terhadap nilai-nilai budaya seperti kebersamaan, negosiasi dan kompromi yang terdapat di dalam setiap budaya. Nilainilai tersebut dipandang sebagai unsur-unsur dalam membangun relasi budaya atau hubungan yang dibangun atas nilai-nilai budaya setempat. Nilai-nilai budaya soméah juga dinilai sebagai pendekatan dalam berkomunikasi persuasif melalui penggunaan bahasa punteun dan mangga. Bahasa ini menekankan bahwa adanya kompetensi komunikasi yang diawali dari diri sendiri (self), yakni berupa kepribadian yang menjunjung tinggi etika dan tata krama dalam berkomunikasi. 
Nilai-nilai budaya soméah yang dianggap sebagai kepribadian atau brand personality masyarakat Suku Sunda sudah sangat melekat. Brand personality tersebut dibentuk karena penilaian masyarakat terhadap kepribadian masyarakat Suku Sunda. Brand personality merupakan hal yang dinamis dan beragam. Artinya, bahwa brand personality itu bukanlah suatu hal yang statis, namun berubah menurut pengalaman hidup seseorang. Karenaya, masyarakat Suku Sunda sudah seyogyanya konsisten memperkenalkan nilai-nilai budaya soméah tersebut melalui perilaku komunikasi. Adanya perilaku komunikasi yang berkesinambungan akan mendorong penilaian positif terhadap brand personality masyarakat Suku Sunda. Kavaratzis dalam (Rezvanpour \& Bayat, 2017) menjelaskan bahwa diantara konsep penting brand personality yaitu identitas. Meskipun konsep brand awalnya brangkat dari brand produk, akan tetapi brand juga berkaitan dengan kepribadian sebagai wujud produk berupa karakter individu. Brand personality menjadi lebih kuat dan melekat dibenak masyarakat karena adanya interaksi dan komunikasi.

Proses menanamkan brand personality dalam istilah public relations disebut personal branding, yakni upaya untuk menyampaikan informasi, memperkenalkan tentang brand kepada publik atau masyarakat melalui interaksi dan komunikasi. Prinsip dasar dari komunikasi yakni adanya proses transaksional (Suranto, 2010). Upaya personal branding terhadap nilai-nilai budaya soméah sebagai brand personality, mencerminkan transaksi dengan landasan komunikasi sosial budaya. Transaksi yang berjalan dinamis dan berkesinambungan dengan landasan budaya. Personal branding atau transaksi, keduanya mempertukarkan simbol, gagasan, pesan dari satu pihak ke pihak lain yang bertujuan untuk mengenalkan dan menanamkan pemahaman kepada publik. Indikator keberhasilan personal branding berupa penilaian atau dukungan dan kepercayaan publik. Kesan positif yang berkesinambungan dapat membangun citra masyarakat Suku Sunda yang dikenal sebagai masyarakat yang soméah yaitu masyarakat yang rendah hati, hormat, sopan dan terbuka.

Personal branding sebagai transaksi juga membuka jalan bahwa budaya soméah dapat dipelajari oleh siapa pun karena pada prinsipnya budaya bersifat dinamis. Untuk itu, transaksi budaya dibagikan tidak hanya sesama suku, akan tetapi antar suku. Transaksi budaya tersebut menyebabkan terjadinya akulturasi pada masyarakat nonpribumi yang hidup berdampingan dengan masyarakat Suku Sunda. Akulturasi dapat diartikan sebagai proses integrasi dan berasimilasi (Bliuc, McGarty, Badea, \& Boza, 2018). Williams \& Berry mendefinisikan akulturasi sebagai proses yang dapat terjadi ketika antarmuka budaya (Cromer et al., 2018). Akulturasi dapat bersifat terarah, akan tetapi dipengaruhi oleh sejauh mana seseorang menyesuaikan karakteristik budaya yang dominan yang ada disekitarnya. Menurut Garcia \& Ahler, adaptasi karakteristik tersebut dapat melibatkan mengintegrasikan keyakinan, kebiasaan, dan bentuk pakaian (Cromer et al., 2018). Akulturasi artinya proses bergabungnya budaya dengan tidak menghilangkan budaya aslinya. Personal branding, selain membuka terjadinya transaksi budaya, juga bertujuan untuk menegaskan bahwa budaya sifatnya organik atau terbentuk karena kekuatan budaya yang bersifat turun-temurun. Demikian halnya dengan budaya soméa $h$ yang senantiasa diyakini atas dasar keteladanan dari orangtua dan sesepuh adat yang sifatnya diwariskan. Dengan demikian, mewarisi budaya soméah dipandang sebagai kebanggaan masyarakat Suku Sunda. Bahkan untuk menjaga kelestariannya, masyarakat Suku Sunda menyadari perlu adanya dukungan dan pengakuan publik atau masyarakat. Dukungan tersebut dapat melahirkan relasi budaya atau hubungan yang dilandasi oleh nilai-nilai budaya masyarakat Suku Sunda.

\section{SIMPULAN}

Upaya memperkenalkan nilai budaya soméah sebagai brand personality dapat dilakukan melalui tindakan personal branding. Tindakan yang dapat dijumpai pada setiap konteks perilaku komunikasi masyarakat Suku Sunda, baik antar sesama maupun dengan lingkungan sekitar. Tindakan personal branding sebagai upaya mensosialisasikan nilai-nilai budaya masyarakat Suku Sunda dengan memperhatikan strategi sebelum berkomunikasi meliputi aspek Insight, Porgram Strategic, Program Implementation, Action and Reputation atau disingkat IPPAR Model. 
Tindakan personal branding berupa perilaku komunikasi yang konsisten dan terpolakan mendorong lahirnya relasi budaya atau hubungan yang dilandasi oleh nilai-nilai budaya masyarakat Suku Sunda. Relasi budaya menjadi bukti kekuatan dan dukungan masyarakat Suku Sunda dalam mengenalkan dan membangun pemahaman tentang nilai-nilai budaya soméah sebagai brand personality masyarakat Suku Sunda, berupa pesan komunikasi verbal yaitu kata punten dan mangga. Pesan komunikasi yang menarasikan nilai-nilai ajakan, mempersilahkan, penawaran, permohonan, dan meminta maaf.

Hasil penelitian ini tentunya masih sangat terbuka untuk dikembangkan karena fokus pada artikel ini baru pada nilai-nilai budaya soméah. Tentu saja masih banyak budaya lainnya yang dapat melengkapi tentang kepribadian masyarakat Suku Sunda selain soméah. Hal ini menjadi bagian dari rekomendasi atau saran, agar peneliti berikutnya dapat mengembangkan hasil penelitian ini. Adanya penelitian lanjutan diharapkan mampu menghasilkan nilai-nilai budaya masyarakat Suku Sunda yang lebih komprehensif.

\section{DAFTAR PUSTAKA}

Alifahmi, H. (2012). Proceeding strategi communication branding di era industri kreatif. In Integrated Communication Branding Dari Personal, Corporate Branding Menuju Country Reputation. (pp. 1-21). Malang: Universitas Brawijaya.

Amron, A. (2018). The influence of brand image, brand trust, product quality, and price on the consumer' $\mathrm{s}$ buying decision of MPV cars, 14(13), 228-239. https://doi. org/10.19044/esj.2018.v14n13p228.

Aw, S. (2010). Komunikasi sosial budaya (1st ed.). Yogyakarta: Graha Ilmu.

Bliuc, A. M., McGarty, C., Badea, C., \& Boza, M. (2018). Enacting collective support for the European integration: Participation in pro-integration action and preference for specific transnational acculturation strategies. Journal of Community and Applied Social Psychology, 28(1), 15-28. https://doi.org/10.1002/casp.2337.

Cromer, L. D. M., Gray, M. E., Vasquez, L., \& Freyd, J. J. (2018). The relationship of acculturation to historical loss awareness, institutional betrayal, and the intergenerational transmission of trauma in the American Indian experience. Journal of Cross-Cultural Psychology, 49(1), 99-114. https://doi. org/10.1177/0022022117738749.

Farady, R. \& Sierjames, J. (2018). Identifikasi nilai kemajemukan Indonesia sebagai identitas bangsa dalam iklan Mixagrip versi keragaman budaya. Jurnal Kajian Komunikasi, 6(1), 37-50.

Griffin, E. (2008). A First Look At Communication theory. (T. Z. Ackley, Ed.) (8th ed.). New York: McGraw-Hill.

Hendriana, H. \& Setiyadi, R. (2018). Budaya Sunda. Diakses dari https://dosen. ikipsiliwangi.ac.id/wp-content/uploads/ sites/6/2019/01/BUDAYA-SUNDAFungsi-dan-sejarah-sunda.pptx.

Hidayat, D., Kuswarno, E., Zubair, F., \& Hafiar, H. (2018). Public relations communication behavior through a local-wisdom approach: The findings of public relations components via ethnography as methodology. Malaysian Journal of Communication, 34(3), 56-72.

Hidayat, D., Kuswarno, E., Zubair, F. \& Hafiar, H. (2017). Message platform atribut siger Lampung di dalam kebhinekaan multikultur. Jurnal Kajian Komunikasi, 5(1), 91-101.

Hidayat, D. \& Suhartini, T. (2018). Community empowerment dan product branding SEKHUIT. Jurnal Ilmu Komunikasi Efek (JIKE), 1(2), 41-58.

Kotsi, F. \& Valek, N. S. (2017). Flying with Nicole Kidman or Jennifer Aniston? Brand funnel stages' influence on brand personality. Journal of Travel \& Tourism Marketing, 00(00), 1-12. https://doi.org/10 $.1080 / 10548408.2017 .1360232$.

Kriyantono, R. \& Mckenna, B. (2017). Developing a culturally-relevant public relations theory for Indonesia. Jurnal Komunikasi: Malaysian Journal of Communication, 33(1), 1-16.

Kusuma, D. F., \& Sugandi, M. S. (2018). Strategi pemanfaatan instagram sebagai media komunikasi pemasaran digital yang dilakukan oleh Dino Donuts instagram utilization strategy as a digital marketing communication media by Dino Donuts. Jurnal Manajemen Komunikasi, 3(1). 
Kuswarno, E. (2008). Etnografi komunikasi (1st ed.). Bandung: Widya Padjadjaran.

Leuape, E. S. (2017). Dialetika etnografi komunikasi emik-etik pada kain tenun. Jurnal Kajian Komunikasi, 5(2), 147-158. https://doi.org/10.24198/jkk.v5i2.8637.

Mendayun, I., \& Sjuchro, W. (2018). Efek komunikasi massa program Citizen Report di radio PRFM Bandung. Kajian Jurnalisme, 02, 98-114.

Pakaradena, A., Hafiar, H., \& Nugraha, A. R. (2018). Proses public relations dalam program layar tancap untuk semua oleh SCTV. ProTVF, 2(2). https://doi. org/10.24198/ptvf.v2i2.20817.

Purwaningwulan, M. M. (2017). Strategi public relations industri islamic fashion Indonesia dalam membentuk branding cantik islami. S. Dida, P. Subekti, S. Lukman, R. Dewi, \& F. A. A. Prastowo (Eds.), Public Relations and Branding (pp. 56-70). Bandung: Unpad Press.

R,A.R., Hanretty, C., \& Lettice, F.(n.d.). Political brands: Can parties be distinguished by their online brand personality?
Ray, M., \& Biswas, C. (2011). A study on ethnography of communication: A discourse analysis with Hymes' speaking model. Journal of Education and Practice, 2(6), 33-41.

Rezvanpour, N. \& Bayat, A. (2017). Determining effective urban design within branding strategy due to brand city spaces and evaluating city spaces by assessing the feasibility of using the heat demand-outdoor comparing them to the presented factors. A case study of temperature function. Energy Procedia, 115, 6-17. https://doi. org/10.1016/j.egypro.2017.05.002.

Samovar, L. A., Porter, R. E., \& McDaniel, E. R. (2010). Komunikasi Lintas Budaya; Communication Between Cultures (7th ed.). Jakarta: Salemba Humanika.

Sriramesh, K., \& Vercic, D. (2003). The global public relations handbook. (L. Bathgate, Ed.). London: Laurence Erlbaum Asociates.

Tumoutounews. (2017). Jumlah suku di Indonesia, daftar suku terbesar.

Wasesa, S. A. (2011). Political branding \& public relations. Jakarta: Gramedia. 